JOURNAL OF SECURITY AND SUSTAINABILITY ISSUES

ISSN 2029-7017 print/ISSN 2029-7025 online

2019 September Volume 9 Number 1

http://doi.org/10.9770/jssi.2019.9.1(5)

Scopus

\title{
ASSESMENT OF SUSTAINABLE ECONOMIC DEVELOPMENT FACETS: PECULIARITIES OF FAMILY BUSINESSES SIZE IN SELECTED ECONOMIES
}

\author{
Ilona Skačkauskienè ${ }^{*}$, Beata Ślusarczyk ${ }^{2}$, Magdalena Baryń ${ }^{3}$, Sebastian Kot $^{4}$, Valentinas Navickas ${ }^{5}$ \\ ${ }^{1}$ Faculty of Business Management, Vilnius Gediminas Technical University, Lithuania \\ ${ }^{2,4}$ Faculty of Management, Czestochowa University of Technology, Poland \\ ${ }^{2,4}$ Faculty of Economic and Management Sciences, North-West University: Vaal Campus Vanderbijlpark, South Africa \\ ${ }^{3}$ Faculty of Management, Czestochowa University of Technology, Poland \\ ${ }^{5}$ School of Economics and Business, Kaunas University of Technology, Lithuania \\ E-mails: ${ }^{1} I l o n a . s k a c k a u s k i e n e @ v g t u . l t,{ }^{2}$ beata.slusarczyk@wz.pcz.pl , \\ 3magdabaryn@op.pl, ${ }^{4}$ sebacat@zim.pcz.pl, ${ }^{5}$ valna@ktu.lt
}

Received 10 January 2019; accepted 30 June 2019; published 30 September 2019

\begin{abstract}
Family businesses are identified in many instances as small-scale entities. However, among family businesse, there are many huge corporations, and many of the world's best-known brands are classified as being family orientated. They generate large revenues, which play a very important role in the global economy. In Poland, several examples of well-known brands belonging to families can be found, such as Mokate, Comarch and Farmacol. The aim of the article is to present selected large Polish family businesses against the background of some of the largest family businesses globally and to determine the difference between them. The research followed an empirical approach and is based on the analysis of secondary data sources, such as Ernst \& Young Family Business Yearbook report series from 2015-2017, the Global Family Business Index ranking, and studies on Polish family businesses. The analyses confirmed that many of the global largest enterprises are indeed family businesses. The importance of family businesses in the economy is evident by the fact that in 2015, enterprises from the Global Family Business Index generated revenues higher than the GDP of most countries in the world. None of the large Polish family businesses have yet found their place in the analysed ranking, but also, in Poland, family businesses play a significant role, and some of them generate revenues of several billion dollars. Familism does not prevent enterprises from achieving a significant position in the market the largest family businesses in the world play such a strong role that their success or failure may affect the condition of the entire economy. Polish family businesses are not yet included in this group, but they are constantly growing. It can, therefore, be anticipated that in a few years, Polish family businesses will have a good representation in the Global Family Business Index and will help to ensure sustainable development of the Polish economy.
\end{abstract}

Keywords: sustainable development; family business characteristics, family business, family company, global family business, sustainable development, Poland

Reference to this paper should be made as follows: Skačkauskienė, I.; Ślusarczyk, B.; Baryń, M.; Kot, S.; Navickas, V. 2019. Assessment of sustainable economic development facets: peculiarities of family businesses size in selected economies, Journal of Security and Sustainability Issues 9(1): 51-62. http://doi.org/10.9770/jssi.2019.9.1(5)

JEL Classification: H12, H56, K14, K32

\section{Introduction}

Sustainable economic development of any country depends on viability and overall performance of business companies (e.g. Kuzmin et al., 2019; Havierniková, Kordoš, 2019; Kowo et al., 2019; Suvittawat, A. 2019, etc,). Despite the fact that the number of family businesses and their share in the overall structure of enterprises is still the subject of many debates, the significance of these entities in the economy has already not raised doubts for some time. Their share in the creation of GDP and employment is widely emphasized (Patel et. al., 
2012; Abdellatif et. al., 2010) and researchers increasingly pay attention to different aspects of the operation of family businesses which, on the one hand, have a lot of characteristics in common and, on the other, are characterized by great diversity. Most family businesses are entities belonging to the SME sector; however, in the modern economy, there are examples of large family businesses employing thousands of workers, whose revenues amount to billions of dollars. Although a family business is still quite often associated with a small entity, in fact, many of the most well-known global brands belong to families. The best example is the Wal-Mart company which has been in the top three of the Fortune Global 500 ranking, presenting the largest companies in the world, since 2000 .

Moreover, it has occupied the first position in 13 editions of this ranking (Fortune, 2018b). Family businesses amount to about 1/3 of the companies of this ranking (Javetski et al., 2014) and, in its latest edition (of 2018), in the top ten, there were three family businesses: Wal-Mart (1st position), Volkswagen (7th position) and Berkshire Hathaway (10th position) (Fortune, 2018a). Also, in the Fortune 500 ranking, presenting the largest companies in the USA, family businesses play a significant role $-35 \%$ of all the entities are estimated to be in the hands of families (GrantThornton, 2018).

Also, in Poland, many of the largest companies belong to families. Admittedly, one will not find the leaders of the 200 Largest Polish Companies ranking by the "Wprost" (polish weekly magazine) among them, however, this due to the fact that the top twenty of the ranking was dominated by state actors. However, in further positions, there are well-known family business representatives (Wprost, 2018).

Undoubtedly, the presence of many family businesses on the lists of the Fortune Global 500 and Fortune 500 proves that family businesses can operate as large entities. Therefore, they may strongly affect the economy. Also, in Poland, there are large, widely recognized family businesses, although, undoubtedly, they still operate on a smaller scale than the world giants. The objective of this paper is to present selected large Polish family businesses against the background of the world's largest family businesses and to make an attempt to determine the distance between them. The subsequent part of the paper is organized as follows: the literature review, research methodology, research results, and final conclusions.

\section{The literature review}

Family business is the oldest form of entrepreneurship. It has been the focus of interests of the world scientific communities more less since the 1970s and, in the last two decades, the number of publications devoted to this topic has significantly increased (Sageder et al., 2018; Chrisman et al., 2016). Despite several decades of research, scientists have failed to develop a single approach to the issues related to family businesses and to create a universal, worldwide accepted definition. As pointed out by Mandl (2008), in Europe itself, there are about 90 different definitions; therefore, their standardization would not be an easy task. One of the most widely accepted and quoted definitions of this issue is a classic American definition, according to which the family business has "any legal form, the capital of the company is located in whole or in part in the hands of the family, and at least one family member exercises decisive influence on the management or holds a managerial position themselves with the intention to maintain the venture in the hands of the family" (Frishkoff, 1995). In the stream of the market research, the most popular is the definition by PricewaterhouseCoopers $(\mathrm{PwC})$, saying that the family business is the entity in which the family has at least a $51 \%$ share, family members are the majority of board members and owners are involved in the daily management in the company (Surdej \& Wach, 2010). However, in the case of the companies listed in the stock exchange, family businesses are often considered as the ones in which the family has more than a $20 \%$ share (Liu et al., 2015; Leung et al., 2014). The diversity of definitions brings about that it becomes necessary to order and group them to some extent. One of the ways is to highlight the factors which are emphasized in individual definitions. Cano-Rubio et.al. (2017) distinguish definitions based on one factor (self-perception; ownership; family involvement in business), two (self-perception and ownership; self-perception and management; self-perception and control; self-perception and family involvement; ownership and continuity; ownership and management; ownership and involvement), three (self-perception, ownership and management; ownership, continuity and manage- 
ment) or more (self-perception, ownership, management and continuity; ownership, management, involvement and continuity) factors.

Despite different definitional approaches, there is general agreement that what distinguishes the family business is the interdependence and cooperation of three main components: family, business, and ownership (Tagiuri \& Davis, 1996). This, in turn, equips these entities with specific characteristics affecting their operation (Bednarz et al., 2017). The most frequently mentioned characteristics of family businesses include: striving for sovereignty and independence; striving to maintain the continuity of ownership and to carry out a generational change; a specific system of property relations; close connection between management and the owners' family; shaping the image of a family business through the family ownership system; the need to consider specific ownership and family goals; the impact of family conflicts on the functioning and development of the company; tendency to ossification of organizational structures, especially in the case of long-term management of the company by the owner (Safin, 2007).

The extensive catalogue of characteristics of family businesses is also presented in the studies by Maloni et al. (2017), Del Giudice (2017), Cucculelli \& Bettinelli (2016), Sousa Paiva et al. (2016), Fernández-Olmos et al. (2016) or Jeżak et. al. (2004). Unfortunately, due to the frequent identification of family businesses with micro- and small enterprises, family businesses are often characterized in terms of these two groups of entities and, in many cases, they do not correspond with large family businesses. However, there is a large group of characteristics which describe well the operation of both small and large entities. These, among others, are the propensity to "re-invest in themselves", resistance to the temptation to obtain short-term benefits, relatively high resistance to the recession, strong strategic orientation and constant concern for the quality of products and services resulting from the relationship between the company and the family name (Jeżak, 2014).

\section{Research methodology}

The research is based on secondary sources. The first one is the Global Family Business Index ranking, which provides the data on 500 largest family businesses in the world. The ranking was created by the specialists from the Centre for Family Business operating at the University of St. Gallen in Switzerland and from EY's Global Family Business Centre of Excellence. The ranking was based on the data for 2015. However, the enterprises for which there were no reliable data, were not included in it. Family businesses were found private entities in which the family has more than $50 \%$ of votes and public companies listed on the stock exchange in which the family has at least $32 \%$ of votes.

On the other hand, the research concerning the significance of family businesses for the economy was based on the data from the reports by EY Family Business Yearbook for years 2015-2017. Each of the reports presents the information related to the period two years before; therefore, the analyses will refer to the period of 20132015.

Yet, the information concerning Polish family businesses come from the ranking made by the portal - money. $\mathrm{Pl}$ and the websites of the largest family enterprises (i.e., Grupa AB, Neuca, Farmacol, Unimot, Komputronik, and so on - see table 4). The data collected in this way relate to the year of establishment, the owner's family, presence on the stock exchange and revenues and allowed to compare Polish family businesses with selected companies from the Global Family Business Index ranking.

\section{Results and discussion}

\subsection{Family businesses in the global, regional and national economies}

Many family businesses are listed on the stock exchange. About 1/3 of the American S\&P 500 Index companies is family businesses (Ali et al., 2007), the situation is similar in China (Nikodemska-Wołowik et al., 2017). The report developed by Credit Suisse indicates that half of more than 3500 listed companies from the 10 largest Asian economies are controlled by families (Ghosh, 2018). In the countries of Western Europe, nearly $45 \%$ of 
the listed companies are family businesses (Surdej \& Wach, 2010). In Germany, among the companies listed on the Frankfurt Stock Exchange, half of them are family businesses, in France; their percentage is even higher and amounts to about 57\% (Marjański, 2013). On the Warsaw Stock Exchange, at the end of 2016, there were listed 176 family businesses, which amounted to nearly 20\% of all the entities (GrantThornton, 2018).

The above data clearly indicate that family businesses, including large entities, play an important role in the contemporary economy and helps to ensure sustainable development. This is noticed by the specialists from the Centre for Family Business operating at the University of St. Gallen in Switzerland and from EY's Global Family Business Centre of Excellence who, already for a few years, have been preparing the rankings of the world's largest family businesses. The Global Family Business Index, since this is the name of the ranking, indicates that, in 2015, the 500 largest family businesses generated the revenues of 6792.3 billion USD and employed 24.85 million workers. If they were considered as a single economy, they would occupy the 3rd position (only following the USA and China). They also play a very important role in the economy of individual regions, as shown in Table 1.

Table 1. The values of the selected indicators characterizing the 500 largest family businesses in the world in individual regions.

\begin{tabular}{|c|c|c|c|}
\hline \multirow{2}{*}{ Indicator } & \multicolumn{3}{|c|}{ Year } \\
\hline & 2013 & 2014 & 2015 \\
\hline \multicolumn{4}{|l|}{ Europe } \\
\hline Number of companies & 243 & 232 & 224 \\
\hline Value of production (billion USD) & 2890 & 2740 & 2909 \\
\hline Share in GDP (\%) & 13,2 & 14,8 & 14,5 \\
\hline \multicolumn{4}{|l|}{ North America } \\
\hline Number of companies & 120 & 117 & 139 \\
\hline Value of production (billion USD) & 2300 & 2222 & 2418 \\
\hline Share in GDP (\%) & 12,4 & 11,4 & 12,3 \\
\hline \multicolumn{4}{|l|}{ Latin America } \\
\hline Number of companies & 36 & 36 & 37 \\
\hline Value of production (billion USD) & 466 & 439 & 414 \\
\hline Share in GDP (\%) & 7,7 & 9,8 & 7,9 \\
\hline \multicolumn{4}{|l|}{ Asia-Pacific } \\
\hline Number of companies & 85 & 85 & 87 \\
\hline Value of production (billion USD) & 743 & 737 & 983 \\
\hline Share in GDP (\%) & 4,3 & 3,4 & 3,3 \\
\hline
\end{tabular}

Source: own study based on: Ernst \& Young, 2015; 2016; 2017.

When considering the number of the world's largest family businesses from the perspective of individual regions, it can be observed that, in the whole period, most of them were in Europe and the smallest number in Latin America. However, it should be added that the share of European companies has been falling each year, whereas in 2015 there was recorded a significant increase in their number in North America. In the other two analysed geographical areas, their share was stable with a slight upward trend.

When analysing the data included in Table 1, it is worth pinpointing the share of family businesses in the creation of GDP. This indicator is the highest in Europe, which should not be surprising since there is the majority of the analysed family businesses. Both in Europe and North America, this share amounts to more than $10 \%$, which should be considered as a very high result (taking into account the number of companies, it should be concluded that the 
result of the companies from North America is even more outstanding). The significance of large family businesses for the economy is even better shown by the example of Latin America, where in 2014 only 35 entities were responsible for the creation of $10 \%$ of GDP. This is the evidence that the world's largest family businesses are the strength the authorities of many countries must take into account.

\subsection{Characteristics of the largest family businesses in the world}

As mentioned above, family businesses can grow to large sizes and become important players on the global market. Table 2 presents selected data on the 10 largest family businesses in the world.

Table 2. The 10 largest family businesses in the world in 2015

\begin{tabular}{|c|c|c|c|c|c|c|}
\hline Company & Family & Founding year & $\begin{array}{c}\text { Public/ } \\
\text { Private }\end{array}$ & $\begin{array}{c}\text { Revenue } \\
\text { (USD b) }\end{array}$ & $\begin{array}{c}\text { Employees } \\
\text { (ths. })\end{array}$ & Country \\
\hline Wal-Mart Stores & Walton & 1962 & public & 485,7 & 2200,000 & USA \\
\hline Volkswagen & Porsche \& Piech & 1937 & public & 231,7 & 591,425 & Germany \\
\hline Berkshire Hathaway & Buffett & 1955 & public & 199,9 & 36,127 & USA \\
\hline Ford Motor Company & Ford & 1903 & public & 149,6 & 199,000 & USA \\
\hline EXOR & Agnelli & 1927 & public & 148,1 & 303,247 & Italy \\
\hline Cargill & Cargill & 1865 & private & 120,4 & 153,000 & USA \\
\hline BMW & Quandt & 1916 & public & 100,1 & 122,244 & Germany \\
\hline Koch Industries & Koch & 1940 & private & 100,0 & 100,000 & USA \\
\hline Schwarz Group & Schwarz & 1930 & private & 93,1 & 360,000 & Germany \\
\hline ALDI Group & Albrecht & 1913 & private & 82,2 & 162,579 & Germany \\
\hline
\end{tabular}

Source: own study based on: The Global Family Business Index, 2017

The top ten of the world's largest family businesses is dominated by the entities from the United States and Germany. The only representative of another country is EXOR, whose owner-family comes from Italy. The clear leader in the ranking of the world's largest family businesses is Wal-Mart, which in 2015 generated the revenues of nearly 486 billion USD, which was the result of more than twice better than in the case of Volkswagen, which was the second in this ranking. Also, in terms of employment, Wal-Mart is significantly ahead of its competitors since they employ almost four Times more workers than Volkswagen. Having in mind, however, that Wal-Mart is the leader of the Global Fortune 500 ranking, these data should not be particularly surprising.

The analysis of the 10 largest family businesses in the world shows that these entities are characterized by rather significant discrepancies (among others, in terms of founding time or the level of employment). The situation is similar in the case of all 500 entities included in the Global Family Business Index, which is presented in Figure 1 and Table 3. 


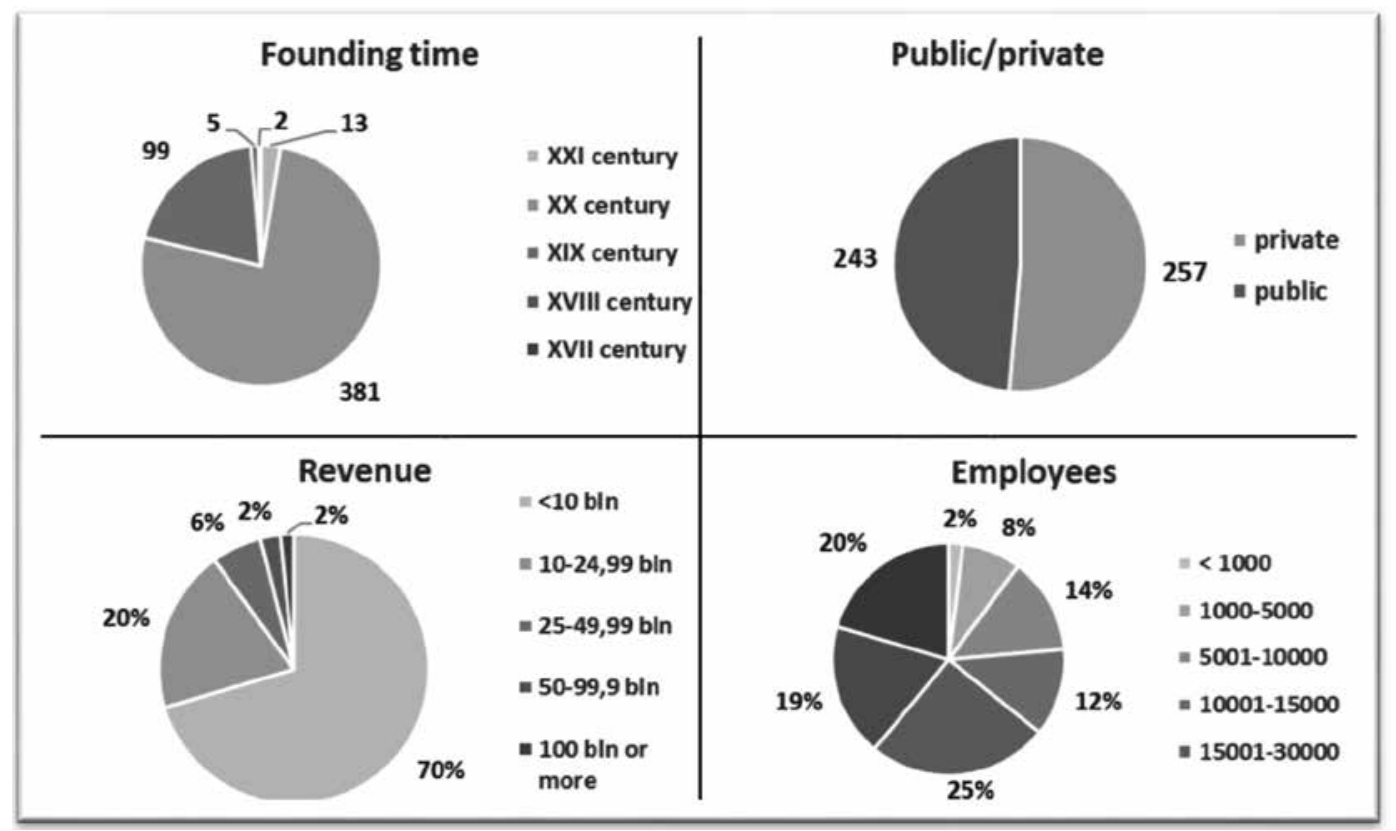

Fig. 1. The selected characteristics of the 500 largest family businesses in the world

Source: own study based on: The Global Family Business Index, 2017

Founding time. A vast majority of the companies included in the ranking of the Global Family Business Index were established in the 20th century (they amount to over $76 \%$ of the total number of the entities). The companies whose origins date back to the 19th century is also quite numerously represented (nearly $20 \%$ of all the companies). Interestingly, in the ranking, there were also two companies founded in the 17 th century, i.e. the ones which may boast of a really long history. This means that the enterprises are able to successfully handle the problems associated with succession and, in this respect, can be a role model for others. On the other hand, the presence of 13 entities established in the 21 st century in the ranking, thus being less than 20 years old, indicates that family business can acquire the status of very large companies in a short time, generating profits counted in billions USD.

Stock exchange. In terms of the presence on the stock exchange, the structure of the world's largest family businesses is balanced. It should be added that among the enterprises which have decided on going public so far, as much as $72 \%$ are the entities being completely in the hands of the family (the family has a $100 \%$ share). Among the companies listed on the stock exchange, in the case of more than $60 \%$ of the entities, the family has the majority of shares (over 50\% of votes). This shows that the world's largest family businesses are very strongly related to the owner-families, which only marginally allow external shareholders. Even if companies go public, families attempt to maintain a significant part of ownership in their hands.

Revenues and employment. A vast majority of the enterprises from the Global Family Business Index ranking generated revenues of less than 10 billion USD in 2015. Only 4\% of the companies generated the revenues of more 50 billion USD, which means that they constitute the group of clear leaders of the ranking. Furthermore, smaller companies are able to grow constantly, thus ensuring sustainable development. In the case of the level of employment, there is much larger balance among the largest companies. The most numerous groups are the entities employing from 5001 to 10000 workers, whereas the least numerous group is the companies with the employment of less than 1000 people. 
Table 3. The selected characteristics of the 500 largest family businesses in the world

\begin{tabular}{|c|c|c|c|c|}
\hline & Max. value & Min. value & Average value & Median \\
\hline Age (years) & 408 & 11 & - & 71 \\
\hline Employment & 2200000 & 226 & 47.692 & 22.317 \\
\hline Revenues (billion USD) & 485,7 & 3.1 & 13,6 & 6,4 \\
\hline Revenues per 1 employee (thousand USD) & 42666.67 & 26.57 & 881.07 & 304.83 \\
\hline
\end{tabular}

Source: own study based on: The Global Family Business Index, 2017.

The data included in Table 3 confirm very large differences between the companies generating the highest and the lowest values of the selected characteristics. In the case of age, the difference between the oldest and the youngest company is 397 years. This indicates that the group of the largest family businesses may include both very young (only 11 years old) and mature, multi-generational (408 years old) entities. It should be noted that the median of age is 71 years, which means that half of the world's largest family businesses had been founded before 1947. Thus they are multi-generational companies. Also, the analysis of the other three characteristics (revenues, employment, and revenues per 1 employee) shows a significant diversity among the enterprises included in the Global Family Business Index. Also, in this case, it is worth paying attention to the median and also the average value. In all the cases, the average value is much higher that the median, which means that most enterprises are characterized by the values considerably, lower than the arithmetic average. This is due to the fact that the enterprises generating the largest revenues significantly go ahead of other entities.

\subsection{Characteristic of largest Polish family businesses}

In Table 4, there are presented the data concerning the 10 largest Polish family businesses.

Table 4. The 10 largest Polish family businesses in 2016

\begin{tabular}{|l|c|c|c|c|}
\hline \multicolumn{1}{|c|}{ Company } & Family & Founding year & Public/ private & Revenue (USD b) \\
\hline Grupa AB & Przybyło & 1990 & public & 2,17 \\
\hline Neuca & Herba & 1990 & public & 1,88 \\
\hline Farmacol & Olszewscy & 1990 & public & 1,61 \\
\hline Unimot & Sikorscy & 1992 & public & 0,67 \\
\hline Komputronik & Buczkowscy & 1996 & public & 0,56 \\
\hline PBG & Wiśniewscy & 1994 & public & 0,50 \\
\hline Wipasz & Wiśniewski & 1994 & private & 0,47 \\
\hline Fermy Drobiu Woźniak & Woźniak & 1986 & private & 0,46 \\
\hline Black Red White & Chmiel & 1991 & private & 0,46 \\
\hline Solaris & Olszewscy & 1996 & private & 0,45 \\
\hline
\end{tabular}

Note: revenues translated from PLN into USD at the average exchange rate of 3.75

Source: own study based on: Stanek, 2017

The history of only one out of the 10 largest Polish family businesses dates back to the times before the political transformation, which took place in 1989. The others were founded in the 1990s, mainly as a result of the aforementioned transformation and market liberalization. These enterprises operate in various industries: among them, among others, there are the representatives of pharmacy (Neuca, Farmacol), distribution (Grupa AB), furniture industry (Black Red White), fuel industry (Unimot) or widely understood agricultural production (Fermy Drobiu Woźniak, Wipasz). This indicates that family businesses may exist, succeed practically, and ensure sustainable development in each sector of the Polish economy. Interestingly, all the three largest 
polish family companies were established in 1990. (i.e., at the very beginning of the political transformation). It seems, however, that it is a rather accidental coincidence. It is worth pinpointing that, as in the case of the world's largest family businesses, going public is not necessary to achieve success although undoubtedly it provides new opportunities since the fact that the leaders of both rankings have decided to go public seems to be important.

In the case of the largest Polish family businesses, it can be observed that there is a high disproportion between the revenues of the top three companies of the ranking and the other entities included in it. The situation is similar to the case of companies from the Global Family Business Index ranking, where the leader Wal-Mart stands out definitely (although the revenues of Volkswagen and Berkshire Hathaway are also definitely higher than the other companies in the ranking), however, as data shows, both smaller and larger family companies are able to grow sustainably

\subsection{Comparison of the largest Polish family businesses with selected companies from the Global Family Business Index ranking}

The companies classified in the Global Family Business Index ranking come from 48 countries. However, there are no representatives of the Polish family business among them. Therefore, it is worth comparing the largest Polish family businesses with selected companies included in this ranking and find out how big the distance between these two groups is. For comparison, the companies that occupy the last five places in the Global Family Business Index ranking have been selected.

Table 5. The 10 largest Polish family businesses in 2016

\begin{tabular}{|l|c|c|}
\hline \multicolumn{1}{|c|}{ Company } & Founding year & Revenue (USD b) \\
\hline World & & \\
\hline Grimaldi Compagnia di Navigazione & 1947 & 3,10 \\
\hline Danieli \& C. Officine Meccaniche & 1914 & 3,10 \\
\hline Brown-Forman Corp & 1870 & 3,10 \\
\hline Jet Airways (India) & 1993 & 3,10 \\
\hline Arcos Dorados Holdings & 2007 & 3,10 \\
\hline Poland & & \\
\hline Grupa AB & 1990 & 2,17 \\
\hline Neuca & 1990 & 1,88 \\
\hline Farmacol & 1990 & 1,61 \\
\hline Unimot & 1992 & 0,67 \\
\hline Komputronik & 1996 & 0,56 \\
\hline
\end{tabular}

Source: own study based on: Stanek, 2017; the Global Family Business Index, 2017

The clear leader of Polish companies is Grupa AB, whose revenues exceeded 2 billion USD. They are by about 1 billion USD too low to be included in the Global Family Business Index ranking but it seems that, over the next few or several years, this company has the best chance to enter the aforementioned ranking. Also, Neuca and Farmacol may hope for that. However, they need slightly more to achieve this target. It is worth noting that two of the companies from the Global Family Business Index ranking were founded later than Polish leaders, which means that the year of founding does not play a significant role. This argument cannot, therefore, explain the lack of representatives of the Polish economy in this ranking. One should, therefore, consider the real reasons for this state of affairs, which may be an interesting topic for future research. 


\section{Conclusion}

Family businesses are the focus of the growing interest; however, it is still possible to identify many research gaps. One of them is the characteristics of family entrepreneurship from the point of view of large entities since, in the subject literature, there dominate the approaches focused on micro- and small entities which, despite possessing many characteristics in common with large family businesses, significantly differ from them. This can be seen clearly on the example of characteristics of family businesses which very well reflect the specificity of smaller entities but do not necessarily relate to the largest entities. Meanwhile, large family businesses may boast of great significance for the economy, especially in terms of sustainability. Therefore, it is worth analysing them in a little more extensive manner.

The world's largest family businesses classified in the ranking of the Global Family Business Index are characterized by a large diversity in terms of the amount of revenues, employment, operating time or share in public trading, however, most importantly, they play a very important role in the economy. Only two countries: the USA and China generate a higher value of GDP than the 500 largest family businesses in total, which certainly is an outstanding result. Also, in individual regions of the world, the entities being in the hands of families are of great importance. In Europe and Latin America, in 2014, which was the year of recession, the largest family businesses increased their GDP share, which means that they can handle problems better than other enterprises. All of this brings about that the entities from the ranking of the Global Family Business Index are important players in the world market.

The largest Polish family businesses still cannot boast of such great importance since they have no representative in the aforementioned ranking. The distance between them and the leaders of the Global Family Business Index is enormous; however, the same can be stated in relation to the entities occupying the final positions of the ranking. The difference in revenues between the largest Polish family businesses and the entities closing the aforementioned ranking is significantly smaller, and it seems quite real to mitigate. This allows for hoping that, in the next few or several years, at least one representative of the Polish family business will enter this prestigious group.

The analysis of the distance of the largest Polish family businesses conducted in this paper is burdened with a few constraints. Firstly, there is certain incompatibility of the research periods since, in the case of the entities from the ranking of the Global Family Business Index, the data concerning revenues come from 2015, whereas, in the case of the Polish companies, they relate to 2016. Secondly, the definitional grounds determining the business as the family one is different. Finally, thirdly, the revenues of Polish family businesses are counted in zloty. Therefore, it was necessary to translate them into USD, which may result in exchange rate differences and to some extent impedes the comparative analysis. This analysis is merely the contribution to further research and indicates its interesting direction. In the future, it would be worth expanding at least the issues related to employment (due to lack of reliable data concerning employment in Polish enterprises, it was impossible to compare this aspect in the present paper), market share or the scale of foreign expansion and, most of all, the analysis of changes taking place over a few years. Another interesting direction of the research can be the comparison of the largest family businesses from a few countries, e.g. from Central and Eastern Europe, which would allow for indicating how the Polish family business operates against the background of similar businesses conducted in the countries of the former socialist bloc. In view of the fact that the largest world and Polish family companies are listed companies, it is also worth investigating whether this is coincidence or whether there are some dependencies in this aspect. 


\section{References}

Abdellatif, M., Amann, B., Jaussaud J. (2010) Family versus nonfamily business: A comparison of international strategies. Journal of Family Business Strategy, 1: 108-116. https://doi.org/10.1016/j.jfbs.2010.04.004

Ali, A., Chen, T.-Y., Radhakkrishnan, S. 2007. Corporate disclosures by family firms. Journal of Accounting and Economics, 44: 238286.

Bednarz, J., Bieliński, T., Nikodemska-Wołowik, A. \& Otukoya, A. 2017. Sources of the Competitive Advantage of Family Enterprises: An International Approach Focusing on China, Nigeria and Poland. Entrepreneurial Business and Economics Review, 5(2): $123-142$.

Cano-Rubio, M., Fuentes-Lombardo, G. \& Vallejo-Martos, M.C. 2017. Influence of the lack of a standard definition of "family business" on research into their international strategies. European Research on Management and Business Economics, 23: $132-146$.

Chrisman, J.J., Chua, J.H., De Massis, A., Minola, T. \& Vismara S. 2016. Management processes and strategy execution in family firms: from "what" to "how". Small Business Economics, 47: 719-734.

Cucculelli, M. \& Bettinelli, C. 2016. Corporate governance in family firms, learning and reaction to recession: Evidence from Italy. Futures, 75: 92-103.

Del Giudice, M. 2017. Understanding family-owned business groups. Towards a Pluralistic Approach, Palgrave Macmillan, Washington.

Ernst\&Young. 2015. Family Business Yearbook.

Ernst\&Young. 2016. Family Business Yearbook.

Ernst\&Young. 2017. Family Business Yearbook.

Fernández-Olmos M., Gargallo-Castel A. \& Giner-Bagües E. 2016. Internationalization and performance in Spanish family SMES: The W-curve. Business Research Quarterly, 19: 122-136.

Fortune 2018a. Global 500. http://fortune.com/global500/list Date of access: 07 January 2019.

Fortune 2018b. Walmart. http://fortune.com/global500/walmart/ Date of access: 07 January 2019.

Frishkoff P.A. 1995. Understanding Family Business, Austin Family Business Program, 15 April.

Ghosh S. 2018. Banker directors and firm performance: Are family firms different?. Future Business Journal, 4: 1-15.

Global Family Business Index 2017. http://familybusinessindex.com/ Date of access: 29 December 2018.

Grant Thornton 2018. Rodzinny biznes na Giełdzie. Analiza Spółek Rodzinnych notowanych na Giełdzie Papierów Wartościowych w Warszawie [A family business on the Stock Exchange. Analysis of Family Companies listed on the Warsaw Stock Exchange], Warszawa.

Havierniková, K., Kordoš, M. 2019. Selected risks perceived by SMEs related to sustainable entrepreneurship in case of engagement into cluster cooperation. Entrepreneurship and Sustainability Issues, 6(4), 1680-1693. http://doi.org/10.9770/jesi.2019.6.4(9)

Javetski B., Murphy C. \& Staples M. 2014. Perspectives of Founder-and Family-Owned Businesses, McKinsey\&Company, Nowy Jork.

Jeżak J. 2014. Przedsiębiorczość rodzinna na świecie - rola i znaczenie oraz cechy specyficzne [Family entrepreneurship in the world role and meaning as well as specific features

], in Jeżak J. (Ed.), Przedsiębiorstwa rodzinne w Polsce. Znaczenie ekonomiczne oraz strategiczne problemy rozwoju, Wyd. UŁ, Łódź, pp. 13-23.

Jeżak J., Popczyk W. \& Winnicka-Popczyk A. 2004. Przedsiębiorstwo rodzinne. Funkcjonowanie i rozwój [A family enterprise. Functioning and development], Difin, Warszawa.

Kowo, S. A., Adenuga, O. A. O., Sabitu, O.O. 2019. The role of SMEs development on poverty alleviation in Nigeria. Insights into Regional Development, 1(3), 214-226. https://doi.org/10.9770/ird.2019.1.3(3)

Kuzmin, E.A., Vinogradova, M.V., Guseva, V.E. 2019. Projection of enterprise survival rate in dynamics of regional economic sustainability: case study of Russia and the EU. Entrepreneurship and Sustainability Issues, 6(4), 1602-1617. https://doi.org/10.9770/ jesi.2019.6.4(4) 
Leung S., Richardson G. \& Jaggi B. 2014. Corporate board and board committee independence, firm performance, and family ownership concentration: An analysis based on Hong-Kong firms. Journal of Contemporary Accounting and Economics, 10: 16-31.

Liu Q, Luo T. \& Tian G.G. 2015. Family control and corporate cash holdings: Evidence from China. Journal of Corporate Finance, 31: $220-245$.

Maloni M.J., Hiatt M.S. \& Astrachan J.H. 2017. Supply management and family business: A review and call for research. Journal of Purchasing \& Supply Management, 23: 123-136.

Mandl I. 2008. Overview of Family Business Relevant Issues. Final Report, KMU Forschung Austria, Wien.

Marjański A. 2013. Rodzinne grupy kapitałowe. [Family capital groups]. Przedsiębiorczość i Zarządzanie, 14(6), part 1: $223-234$.

Nikodemska-Wołowik A.M., Bieliński T. \& Bednarz J. 2017. Gospodarcze i społeczno-kulturowe uwarunkowania rozwoju chińskich przedsiębiorstw rodzinnych [Economic and socio-cultural conditions for the development of Chinese family enterprises]. Przedsiębiorczość i Zarządzanie, 18(6), part 1:211-224.

Patel V.K., Pieper T.M. \& Hair Jr J.F. 2012. The global family business: Challenges and drivers for cross-border growth. Business Horizons, 55: 231-239.

Sageder M., Mitter Ch. \& Feldbauer-Durstmüller B. 2018. Image and reputation of family firms: a systematic literature review of the state of research. Review of Managerial Science, 12: 335-377.

Safin K. 2007. Przedsiębiorstw rodzinne - istota i zachowania strategiczne [Family enterprises - the essence and strategic behaviors], wyd. AE we Wrocławiu, Wrocław.

Sousa Paiva I., Costa Lourenço I. \& Castelo Branco M. 2016. Earnings management in family firms: current state of knowledge and opportunities for future research. Review of Accounting and Finance, 15(1): 85-100.

Stanek A. 2017. W rodzinie siła. 10 największych firm rodzinnych w Polsce, https://www.money.pl/galerie/artykul/top-10-rodzinnychfirm-w-polsce,113,0,2365297.html Date of access: 07 January 2019.

Surdej A. \& Wach K. 2010 Przedsiębiorstwa rodzinne wobec wyzwań sukcesji, Difin, Warszawa.

Suvittawat, A. 2019. Passions and enthusiasm of small and medium enterprises (SMEs): A case study of Nakorn Ratchasima province, Thailand. Entrepreneurship and Sustainability Issues, 6(3), 1169-1179. http://doi.org/10.9770/jesi.2019.6.3(22)

Tagiuri R. \& Davis J. 1996. Bivalent Attributes of the Family Firm. Family Business Review, 9(2): 199-208.

Wprost. 2018. 200 największych polskich firm 2018 [The 200 largest Polish companies 2018] https://rankingi.wprost.pl/200-najwiekszych-firm\#pelna-lista Date of access: 07 January 2019. 


\section{Ilona SKAČKAUSKIENE்}

Doctor of Social Sciences, Professor, Head of Department of Management at Vilnius Gediminas Technical University (Lithuania). She has experience of over 15 years in research work and over seven years in staff leading. Prepared two doctors of social (management) science; now, she is a research supervisor of 2 persons maintaining a doctor's thesis of social (management) science. She has published over 50 publications during her scientific period and read reports in Lithuanian and international conferences. Fields of scientific interest cover the creation process of new services, social and economic development, social innovation management.

ORCID ID: https://orcid.org/0000-0002-5078-3678

\section{Beata ŚLUSARCZYK}

Doctor of management, associated professor at Czestochowa University of Technology, The Management Faculty (Poland); extraordinary professor at North-West University, Faculty of Economic and Management Sciences, South Africa. Prof. Beata Ślusarczyk has over 20 years of teaching, research, and managerial experience in higher education. She has published widely, and her publications include books, book chapters, refereed journals' papers as well as conference proceedings or books reviews. Fields of scientific interest: Industry 4.0, logistics costs, economy globalization, women entrepreneurship, restructuring of enterprises.

ORCID ID: http://orcid.org/0000-0002-7276-8372

\section{Magdalena BARYN}

Graduate of the Management and Logistics at Faculty of Management in Czestochowa University of Technology. Ph.D. student at the Faculty of Management at Czestochowa University of Technology.

Author and co-author of over of dozen articles published in Poland and abroad. Participant in several national and international scientific conferences. Fields of scientific interests: family business, logistics, enterprise's goals, ISO standards.

ORCID ID: http://orcid.org/0000-0003-1199-8892

\section{Sebastian KOT}

Doctor of management, associated professor at Czestochowa University of Technology, The Management Faculty (Poland); extraordinary professor at North-West University, Faculty of Economic and Management Sciences, South Africa.

E-mail: sebacat@zim.pcz.pl

He is currently Professor in management and supply chain management and Vice Director of the Institute of Logistics at Faculty of Management, Czestochowa UT He has over 19 years of teaching, research and managerial experience in higher education. He is a Founder and Co-editor of the Polish Journal of Management Studies. He is a Member of Editorial Board: Advanced Logistics Systems; Supply Chain Management Journal. Fields of scientific interest: supply chain management, logistics, entrepreneurship.

ORCID ID: http://orcid.org/0000-0002-8272-6918

\section{Valentinas NAVICKAS}

Doctor of social sciences (economics), professor at Kaunas University of Technology (Lithuania), the School of Economics and Business. Author of more than 300 scientific publications (including monographies published in the Czech Republic in 2013 and Slovak Republic in 2016, 2018) and scientific articles, published in Lithuania and abroad. Author of five experimental development projects. Prepared 5 doctors of social (economics) science; now he is research adviser of 2 persons maintaining a doctor's thesis of social (economics) science. Fields of scientific interest: international economics, clusterization, competitiveness, economic growth, corporate social responsibility.

ORCID ID: https://orcid.org/0000-0002-7210-4410

This work is licensed under the Creative Commons Attribution International License (CC BY).

http://creativecommons.org/licenses/by/4.0/ 